\title{
Incidental Finding of Squamous Cell Carcinoma Accompanying a Fungal Ball in the Maxillary Sinus
}

\author{
Hyun Ju Lee ${ }^{1}$, Jung Soo Kim ${ }^{1} \mathbb{D}$, and Sung Jae Heo $^{2} \mathbb{D}$ \\ ${ }^{1}$ Department of Otorhinolaryngology-Head and Neck Surgery, School of Medicine, Kyungpook National University, \\ Kyungpook National University Hospital, Daegu; and ${ }^{2}$ Department of Otorhinolaryngology-Head and Neck Surgery, School of Medicine, \\ Kyungpook National University, Kyungpook National University Chilgok Hospital, Daegu, Korea
}

\section{상악동의 진균구에서 우연히 발견된 편평세포암}

이현주 ${ }^{1} \cdot$ 김정수 $^{1} \cdot$ 허성재 $^{2}$

경북대학교 의과대학 경북대학교병원 이비인후-두경부외과학교실, ${ }^{1}$ 경북대학교 의과대학 칠곡경북대학교병원 이비인후-두경부외과학교실 ${ }^{2}$

\author{
Received February 16, 2019 \\ Revised June 8, 2019 \\ Accepted June 19, 2019 \\ Address for correspondence \\ Sung Jae Heo, MD \\ Department of Otorhinolaryngology- \\ Head and Neck Surgery, \\ School of Medicine, \\ Kyungpook National University \\ Chilgok Hospital, \\ 807 Hoguk-ro, Buk-gu, \\ Daegu 41404, Korea \\ Tel +82-53-200-2792 \\ Fax +82-53-200-2027 \\ E-mail blueskyhsj@hanmail.net
}

\begin{abstract}
Malignant tumors rarely occur in the paranasal sinuses. Paranasal tumors, when they occur, exhibit atypical symptoms, such as nasal obstruction, rhinorrhea, facial pain, and nasal bleeding. Because of nonspecific symptoms commonly observed in the sinusitis and their infrequent occurrence, malignant tumors of the paranasal sinuses are generally diagnosed late. If there is bone destruction or invasion of the surrounding tissues in the imaging studies, malignant tumors could be suspected; however, without such findings, it is difficult to predict the existence of cancer. It is more difficult to suspect malignant tumors when they coexist with sinus diseases. In addition, since the concomitant presence of fungal balls and cancer is extremely rare, it is difficult to suspect the presence of cancer when treating fungal balls. We report a case of a fungal ball accompanied by squamous cell carcinoma without any sign of malignancy, such as bone destruction, which has not been reported in the English literature to date. Korean J Otorhinolaryngol-Head Neck Surg 2020;63(4):172-5
\end{abstract}

Key Words Fungi $\cdot$ Maxillary sinus $\cdot$ Mycoses $\cdot$ Nose $\cdot$ Squamous cell carcinoma.

\section{Introduction}

Malignant tumors in the sinuses account for approximately $5 \%$ of all head and neck malignancies and occur annually in approximately 1 per 100000 individuals worldwide. ${ }^{1)}$ The mean age at onset is 50-60 years, and symptoms are atypical, such as nasal obstruction, facial pain, rhinorrhea, and nasal bleeding. ${ }^{2)}$ They are usually diagnosed after the disease progresses because the symptoms or signs are similar to those of benign paranasal sinus diseases. Therefore, approximately 10$20 \%$ of patients have lymph node metastasis at the first diag-

This is an Open Access article distributed under the terms of the Creative Commons Attribution Non-Commercial License (https://creativecommons.org/licenses/by-nc/4.0) which permits unrestricted non-commercial use, distribution, and reproduction in any medium, provided the original work is properly cited. nosis. ${ }^{3)}$ The most common type of tumor is squamous cell carcinoma (SCC, 50-80\%), followed by adenocarcinoma (10$20 \%)$.

Approximately $13.5 \%$ to $28.5 \%$ of maxillary sinusitis is associated with fungal sinusitis. ${ }^{4)}$ The most common form of fungal infection is a fungal ball, which consists of a dense conglomeration of hyphae separated from the sinus mucosa. Fungal balls do not have histological evidence of fungal invasion of the mucosa, blood vessels, or bone when visualized microscopi(ally. ${ }^{5)}$

Fungal balls and SCC are rarely observed together in the paranasal sinuses. Ginat, et al. ${ }^{6}$ reported a case of a concurrent fungal ball and SCC of the maxillary sinus. Since their patient showed disproportionate destruction of the maxilla bone on 
radiological imaging and progressive symptoms despite the treatment for infection control, the possibility of malignancy could be assumed. We report a case of a fungal ball accompanied by SCC without any sign of malignancy, which has not been reported in the English literature to date.

\section{Case}

A 67-year-old man was admitted to our clinic with rhinorrhea and nasal obstruction of the left nasal cavity that had developed approximately 1 month ago. He did not have symptoms such as facial pain, swelling, bleeding, or foul odor. There was no underlying disease except allergic rhinitis in his past history. Although he underwent treatment of dental caries in the right lower first molar 6 months ago, there was no history of dental problem in the upper molar area. Endoscopic examination showed a nasal polyp and mucopurulent discharge in the left nasal cavity (Fig. 1). CT of the paranasal sinuses showed soft tissue density and calcification in the left maxillary sinus, which is consistent with signs of a fungal ball (Fig. 2). There was no feature that was suspicious of malignancy, such as destruction and invasion of the surrounding structures. Endoscopic sinus surgery was planned under local anesthesia for histopathologic diagnosis and treatment with the suspicion of a fungal ball.

A polyp-like mass of the left nasal cavity was removed, and antrostomy was performed. Mucopurulent clay-like material consistent with a fungal ball was found in the left maxillary sinus. Severe edema was observed in the maxillary mucosa, and biopsy was performed (Fig. 3). Histopathologic examination revealed the diagnosis of a nasal polyp and fungal ball consisting of Aspergillus (Fig. 4A) in the nasal cavity and left maxillary sinus, respectively, as expected. However, unexpectedly, edematous mucosal tissue of the posterior maxillary sinus was confirmed as SCC (Fig. 4B).

Positron emission tomography for identification of the primary site and distant metastasis was performed and confirmed stage II (T2N0M0) SCC originating from the left maxillary sinus. The patient underwent concurrent chemotherapy con-

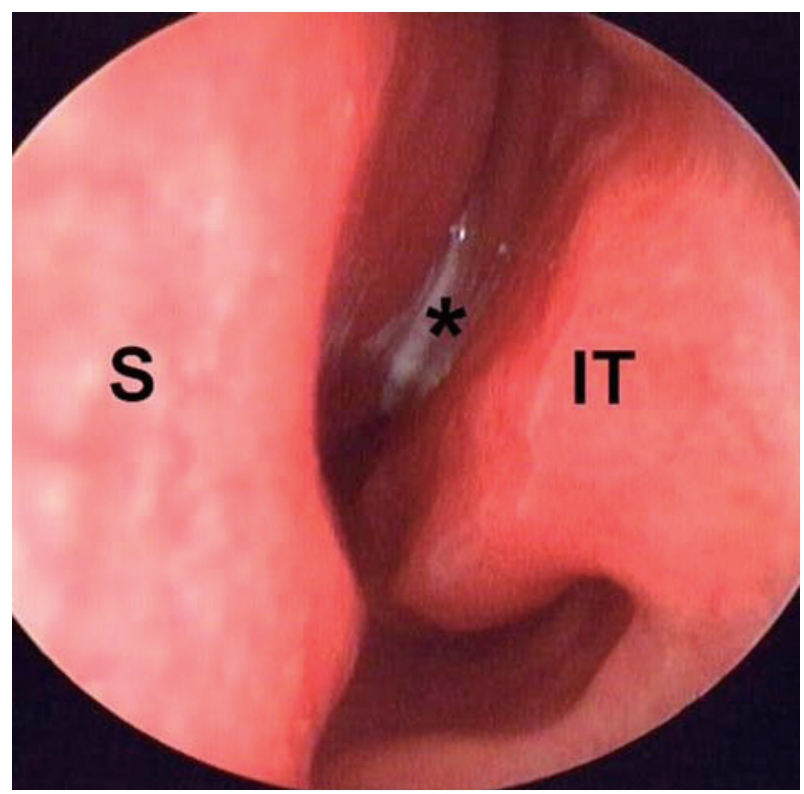

Fig. 1. Endoscopic examination showed a nasal polyp and mucopurulent discharge (asterisk) in the left nasal cavity. S: nasal septum, IT: inferior turbinate.
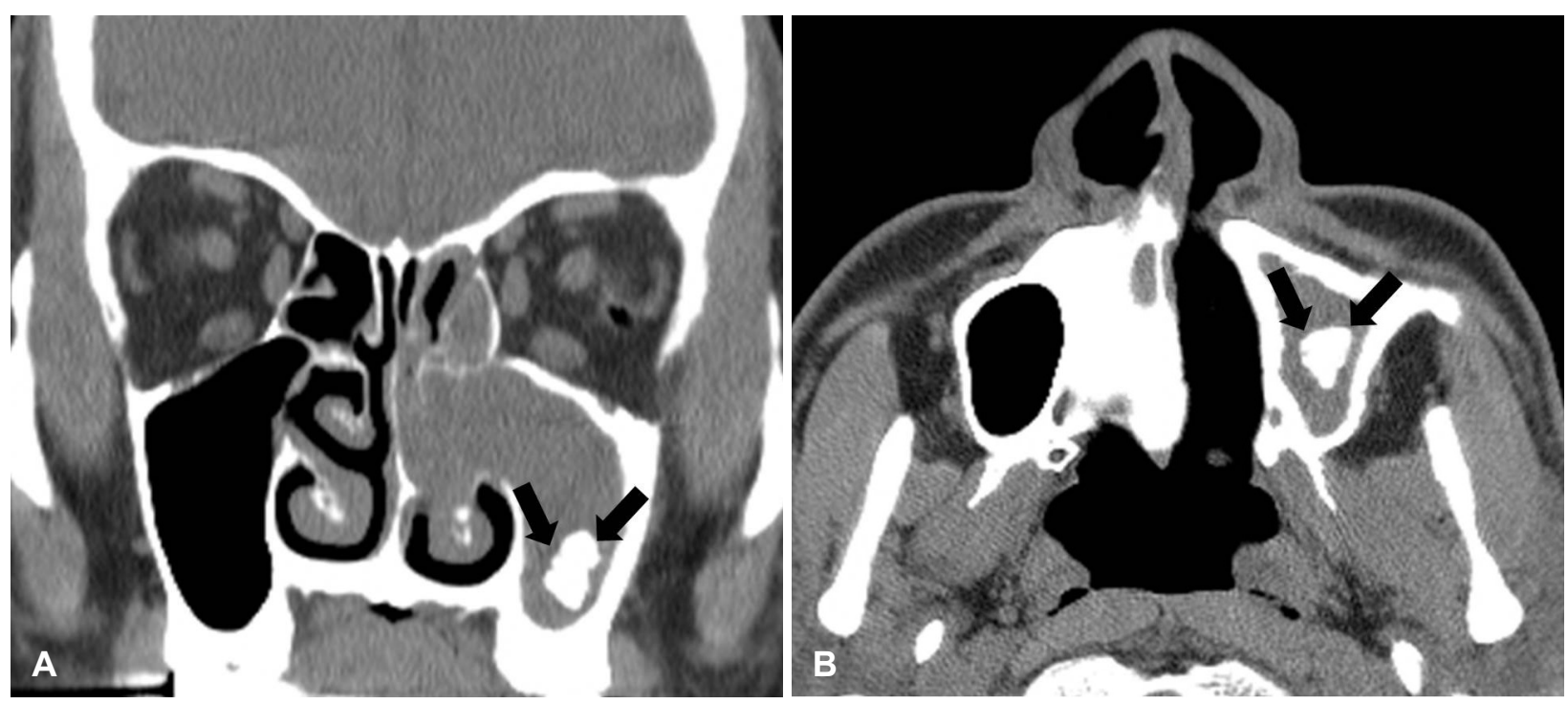

Fig. 2. CT of the paranasal sinuses showed soft tissue density and calcification (arrows) in the left maxillary sinus (A, coronal view; B, axial view). 
sisting of $7260 \mathrm{cGy} / 33$ times radiation therapy in the left maxillary sinus. Positron emission tomography performed 6 months postoperatively showed slightly increased mucosal uptake in the left maxillary sinus, which is a finding corresponding to benign inflammation. No metastases or recurrences were found. Nineteen months after the surgery, a new lesion involving the left ethmoid sinus and orbit was identified. Gamma knife treatment was applied, and no remnant or recurrence have been observed for a year during follow-up.

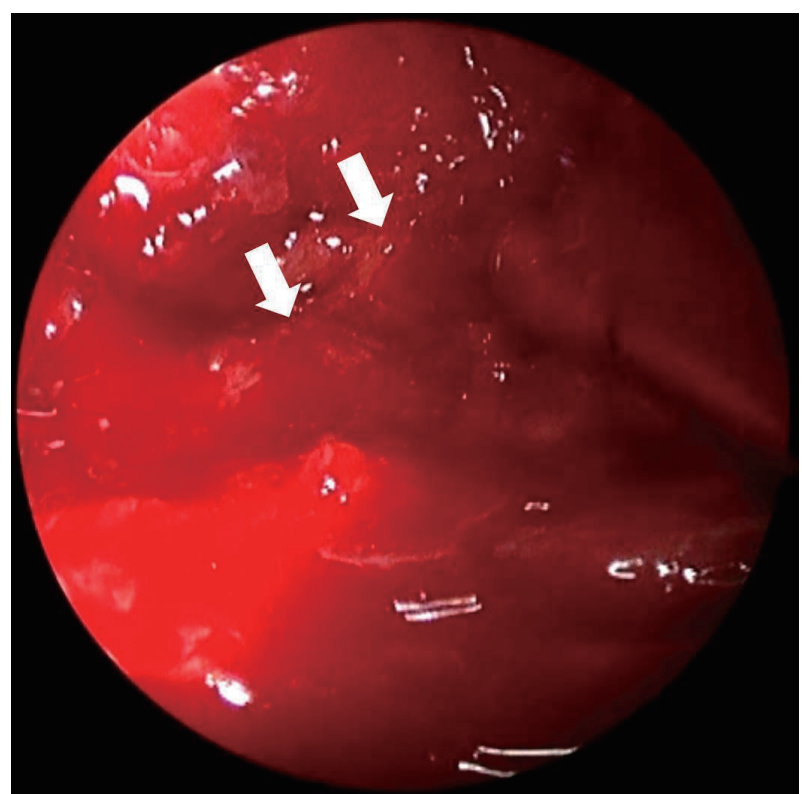

Fig. 3. Edematous mucosa is shown in the posterior wall of the left maxillary sinus (arrows).

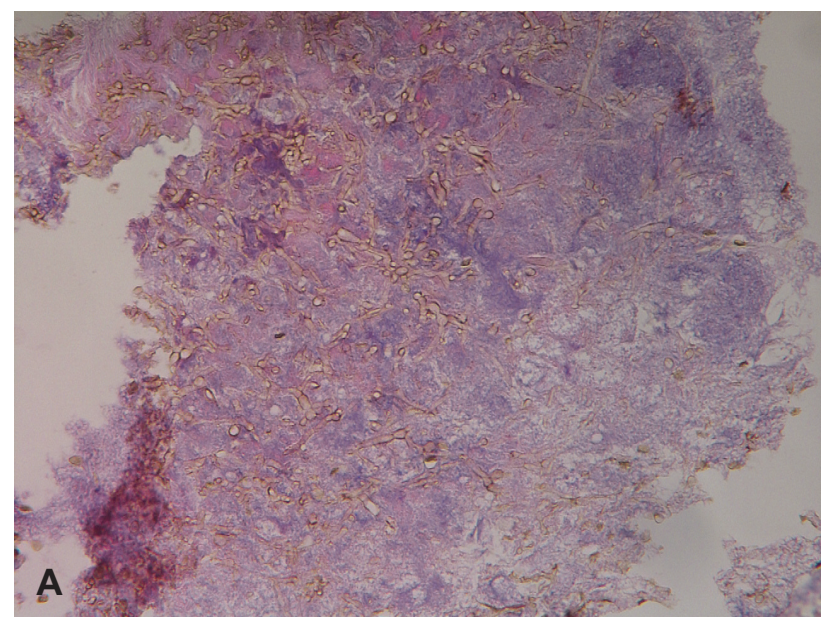

\section{Discussion}

Fungal balls, which are non-invasive accumulations of dense conglomerations of fungal hyphae, usually present in sinus cavities. They occur mainly in the maxillary sinus, but can be observed in other sinuses and rarely in more than one sinus. ${ }^{7)}$ Since most patients with fungal balls are asymptomatic due to the characteristic slow growth of such balls, they are usually detected incidentally and diagnosed late. ${ }^{4)}$ Common symptoms of fungal balls include unilateral purulent discharge, postnasal drip, facial pain, and nasal obstruction. Nasal bleeding, facial pain, and ocular or neurologic symptoms can also be observed.

Diagnosis is based on symptoms of recurrent or refractory sinusitis and typical CT findings including inhomogeneous opacification with central metallic dense spots in the unilateral sinus. Since bone erosion is shown in $4-17 \%$ of cases of fungal balls, ${ }^{8)}$ accompanied cancer may not be predicted when CT shows bone destruction preoperatively. In particular, in fungal ball cases, if there are no symptoms such as bone erosion or pain, cancer is more difficult to be suspected before surgery. In this case, we could not predict the cancer before surgery because there were no findings that were suspicious of malignancy. Furthermore, we also did not suspect cancer during surgery because the intraoperative findings did not have any suspicious features of cancer such as surrounding tissue invasion or a mass. SCC was diagnosed incidentally in a biopsy specimen performed to examine the invasion of fungus or the extent of eosinophils and neutrophils in the mucosa. Based on this case, it is recommended to perform histologic exami-

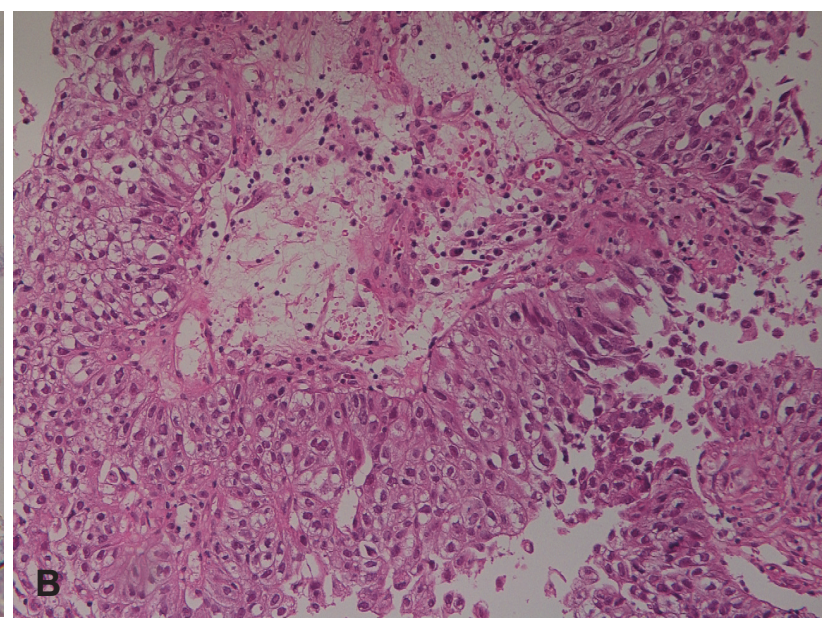

Fig. 4. Numerous septate fungal hyphae are observed in H\&E stained tissue $(A, \times 400)$. The fungal hyphae show septate filaments of regular thickness and branching at acute angles, which are consistent with Aspergillus. Atypical squamous cells, stromal invasion, and intercellular bridge, which are consistent with squamous cell carcinoma, were noted in H\&E stained tissue $(B, \times 200)$. H\&E: hematoxylin and eosin. 
nation of the mucosa with severe inflammation in endoscopic sinus surgery, especially in elderly patients.

SCC may occur first, causing inflammation, resulting in poor ventilation and inappropriate immune mechanisms, resulting in a fungal ball. Although the type of tumor is different, Yeo, et al. ${ }^{9)}$ reported a case of coexistence of small cell carcinoma and fungal ball in the maxillary sinus. They assumed that fungus entered into the maxillary sinus through nasal breathing and was captured in the sinus by mass effect of small cell carcinoma. The tumor might block the ostium of maxillary sinus and cause an anaerobic condition in which the fungus could be colonized. Therefore, it was presumed that fungal ball was secondary to small cell carcinoma. Although it occurred in different sites, Itano, et al. ${ }^{10)}$ reported a case of non-small cell lung cancer coexisting with pulmonary aspergilloma. They hypothesized that the progression of the lung cancer obstructed the bullous air spaces, resulting in the colonization of Aspergillus and occurrence of pulmonary aspergilloma.

However, it is more likely that the fungal ball caused inflammation for a long period in this patient because a polyp and osteitic change of the maxilla bone were observed. In addition, cancer can be caused by inflammation; thus, it is presumed that cancer occurred because of long-term inflammation caused by the fungal ball. However, since there is no apparent evidence that fungus directly induces cancer, it is difficult to elucidate the causal relationship between a concurrent fungal ball and SCC in the paranasal sinuses.

\section{Author Contribution}

Conceptualization: Sung Jae Heo. Data curation: Hyun Ju Lee. Formal analysis: Hyun Ju Lee, Jung Soo Kim, Sung Jae Heo. Investi- gation: Hyun Ju Lee, Sung Jae Heo. Supervision: Jung Soo Kim, Sung Jae Heo. Validation: Jung Soo Kim, Sung Jae Heo. Writing—original draft: Hyun Ju Lee. Writing — review \& editing: Sung Jae Heo.

\section{ORCIDs}

Sung Jae Heo https://orcid.org/0000-0002-1388-8075 Jung Soo Kim

\section{REFERENCES}

1) Llorente JL, López F, Suárez C, Hermsen MA. Sinonasal carcinoma: Clinical, pathological, genetic and therapeutic advances. Nat Rev Clin Oncol 2014;11(8):460-72.

2) Youlden DR, Cramb SM, Peters S, Porceddu SV, Møller H, Fritschi $\mathrm{L}$, et al. International comparisons of the incidence and mortality of sinonasal cancer. Cancer Epidemiol 2013;37(6):770-9.

3) Kuijpens JH, Louwman MW, Peters R, Janssens GO, Burdorf AL, Coebergh JW. Trends in sinonasal cancer in the Netherlands: More squamous cell cancer, less adenocarcinoma. A population-based study 1973-2009. Eur J Cancer 2012;48(15):2369-74.

4) Grosjean P, Weber R. Fungus balls of the paranasal sinuses: A review. Eur Arch Otorhinolaryngol 2007;264(5):461-70.

5) deShazo RD, O’Brien M, Chapin K, Soto-Aguilar M, Swain R, Lyons $\mathrm{M}$, et al. Criteria for the diagnosis of sinus mycetoma. J Allergy Clin Immunol 1997;99(4):475-85.

6) Ginat DT, Johnson DN, de Souza J, Blair E. Concurrent fungus ball and squamous cell carcinoma of the maxillary sinus. Eur Ann Otorhinolaryngol Head Neck Dis 2016;133(2):153-4.

7) Chakrabarti A, Denning DW, Ferguson BJ, Ponikau J, Buzina W, $\mathrm{Kita} \mathrm{H}$, et al. Fungal rhinosinusitis: A categorization and definitional schema addressing current controversies. Laryngoscope 2009; 119(9):1809-18.

8) Klossek JM, Serrano E, Péloquin L, Percodani J, Fontanel JP, Pessey JJ. Functional endoscopic sinus surgery and 109 mycetomas of paranasal sinuses. Laryngoscope 1997;107(1):112-7.

9) Yeo SC, Cho HJ, Kim SW, Jeon SY. A case of small cell carcinoma of the maxillary sinus coexisting with fungus ball. J Rhinol 2016; 23(2):110-4.

10) Itano $H$, Andou A, Date H, Shimizu N. Non-small cell lung cancer coexisting with pulmonary aspergilloma. Jpn J Thorac Cardiovasc Surg 2005;53(9):513-6. 